\title{
VARIATIONS OF WOOD PROPERTIES OF BIRCH (BETULA PENDULA ROTH) FROM A 23-YEAR OLD SEED ORCHARD
}

\author{
Marcin Jakubowski, Arkadiusz Tomczak, Tomasz Jelonek \\ Witold GRZywińsKi \\ Poznan University of Life Sciences \\ Poznań, Poland \\ (Received May 20i9)
}

\begin{abstract}
This work presents the results of selected wood properties in birch trees grown on a provenance experiment plot established as a seed orchard. The study concerned: basic density, oven-dry density and compression strength along the grain at a moisture content of $0 \%$ and at moisture content above fiber saturation point. Analyses were performed on 971 wood samples collected from 28 trees at the level of breast height. It was found high variability for diameter of breast height (22\%) and relatively low for basic density (9\%) and oven-dry density (11\%). Average basic density was $446.5 \mathrm{~kg} \cdot \mathrm{m}^{-3}$ and average oven-dry density was $537.9 \mathrm{~kg} \cdot \mathrm{m}^{-3}$. The compression strength at $0 \%$ moisture content was four times higher $(65 \mathrm{MPa})$ than the strength at moisture content above the fiber saturation point (16.6 MPa). Most of clones had similar properties within the limits of statistical errors, but a few clones exhibited statistically significant low value.
\end{abstract}

KEYWORDS: Forest plantations, seed orchard, compression strength, wood density, wood quality, wood moisture content.

\section{INTRODUCTION}

Wood consumption has increased consistently in recent years in close relation to the popularity of wood as an environmentally friendly material. Wood from stands has better technical parameters than that from plantations, however wood resources in forests are limited, which results in the development of plantations as a natural alternative. In 2001 over 50 million ha of plantations worldwide produced approximately $20 \%$ of harvested timber. In some countries (China, Russia, the United States, Brazil, Indonesia, Sudan, Chile) plantations have become important sources of timber (West 2006, Zwoliński 2008). Wood from plantations has slightly different properties and stem characteristics, limiting its applications considerably. Plantations 
in Europe are generally oriented towards biomass and energy production and contain the tree species belonging mainly to the genera Salix and Populus (Klašnja et al. 2008, Šefc et al. 2015, Mola-Yudego et al. 2017). This is mainly due to plantations being managed as monocultures, however attempts are being made to introduce mixed cultures (Gartner 2005, Kelty 2006). Despite the development of plantations, a decrease in forested area may be observed as a result of timber harvesting (Stibig et al. 2014, Margono et al. 2014). In Poland plantations of fast-growing trees have not been of great importance due to the predominance of the traditional model of forest economy, although the potential use of plantation culture is being considered, particularly for wood as an energy source (Bijak et al. 2013, Szczukowski and Stolarski 2013, Bronisz et al. 2016, Mola-Yudego et al. 2017). The wood industry still requires raw material of a high technological standard. In the case of plantations it is essential to select appropriate genotypes that ensure adequate wood quality. Plantations are typically established using specially prepared seedlings. Seed orchards serve a completely different function, ensuring continuous seed production by specimens with valuable genotypes, although even in this form of plantations the genotype is narrowed down (Przybylski 2015). Seed orchards are established by grafting fragments of maternal trees onto rootstock of the same species. Many experimental plantations in Poland established in previous decades have already reached an age which allows the wood to be examined in depth. Individual specimens have a similar appearance to the maternal trees. By definition the purpose is seed production; however in view of the rapid individual growth and preservation of traits of the maternal tree, it appears appropriate to considering production by vegetative propagation of selected clones. Stems of trees on existing plantations have already reached dimensions sufficient for testing (Jakubowski et al. 2013, Szaban et al. 2014).

Provenance experiments have taken on great importance in recent years, and birch is seen as an important source of good quality wood. Consequently research in this field is being conducted in various European countries, including the United Kingdom (Lee et al. 2015), Finland (Maja et. al. 2015, Haapala et al. 2017), Island (Riege and Sigurgeirsson 2018), Poland (Lachowicz et al. 2019) and others (Cameron 1996, Baliuckiené, and Baliuckas 2006, Henynen et al. 2010), as well as in countries outside Europe such as China (Wang et al. 2015, 2018).

In this work it is assumed that the wood density and compression strength will be different for the tested clones, and this will help in the selection of the most promising specimens. The samples from the seed orchard are unique because of restricted conditions of cuttings. These studies were conducted on wood collected from the last schematic cuttings. The plantation reached the final spacing in 2007. The material from these cuttings is particularly valuable, because further samples may come from incidental cuttings only. All tests were carried out in 2008 and the results were stored in our archives. Due to the growing interest in birch wood, we decided to analyze the collected data. The aim of this study was to compare wood density and compressive strength along the grain in birch wood of various provenances.

\section{MATERIAL AND METHODS}

Plantation Birch II was established in the years 1984-1985 in the Susz Forest Division in north-eastern Poland and was intended for the production of seeds. All plantations in Poland are registered and are under the control of the Forest Research Institute (Register of seed orchards). The plantation was set up in a block design with replications typical of provenance studies. Analyses were performed on 28 clones represented by 28 trees. Diameter at breast height was measured in two directions: north-south and east-west. The measurements were averaged and 
the selected trees were felled. Because all of the trees are of the same age and have the same number of annual rings we omitted the measurement of rings. The experimental material for crash tests consisted of small wood samples with dimensions of $20 \times 20 \times 30 \mathrm{~mm}$ along the grain $(\mathrm{x}, \mathrm{y}, \mathrm{z})$. Samples were collected from the stem cross-section at two levels according to the diagram (Fig. 1). Radial rows of samples were oriented in the east-west direction.
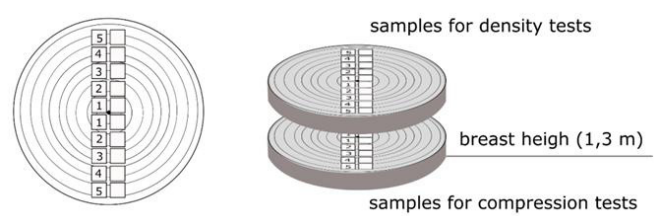

Fig. 1: Scheme for wood sample collection from the stem cross-section.

Mechanical tests were conducted in two ways: first (for row 1) - at a sample moisture content above the fiber saturation point (> 30\%) and second (for row 2) at a moisture content of $0 \%$. Standard mechanical tests are carried out at $12 \%$ of moisture content and we consider this a good point for comparison with other research. Oven-dry wood is rarely used for tests: we do it in order to observe compression strength after drying. Differences between results for wood with moisture content above the fiber saturation point and oven-dry wood may demonstrate certain changes in the wood structure after drying. For the first method, samples were immersed in water for 72 hours. For the second, samples were dried in an electric drier at $105^{\circ} \mathrm{C}$ until they reached constant mass. The mass of samples was measured with laboratory scales to an accuracy of $0.001 \mathrm{~g}$. Dimensions of samples were measured immediately before the crash test with using an electronic caliper. The volume of samples was calculated from the dimensions (x, y, z). Wood strength was determined using a TiraTest 2300 testing machine controlled by Matest Service software. Compression strength along the grain was determined using the following Eq.:

$$
C S_{0 \%}=\frac{F}{A} \quad(\mathrm{MPa})
$$

where: $\mathrm{CS}_{0 \%}$ - compression strength along the grain for oven-dry samples,

$\mathrm{F}$ - the applied load $(\mathrm{N})$,

A - specimen area $\left(\mathrm{mm}^{2}\right)$,

$$
C S_{30 \%}=\frac{F}{A} \quad(\mathrm{MPa})
$$

where: $\quad \mathrm{CS}_{>30 \%}$ - compression strength along the grain for wet samples (moisture content above fiber saturation point),

$\mathrm{F}$ - the applied load $(\mathrm{N})$,

A - specimen area $\left(\mathrm{mm}^{2}\right)$.

Oven-dry density was determined using the following Eq.:

$$
O D=\frac{M_{0 \%}}{V_{0 \%}} \quad\left(\mathrm{~kg} \cdot \mathrm{m}^{-3}\right)
$$

where: $\mathrm{OD}=$ oven-dry density,

$\mathrm{M} 0 \%=$ mass of sample at $0 \%$ moisture content,

$\mathrm{V} 0 \%=$ volume of sample at $0 \%$ moisture content. 
Basic density (green density) was determined using the following Eq.:

$$
B D=\frac{M_{0} \%}{V_{\max }} \quad\left(\mathrm{kg} \cdot \mathrm{m}^{-3}\right)
$$

where: $\mathrm{BD}$ - basic density,

$\mathrm{M}_{0 \%}$ - mass of sample at $0 \%$ moisture content,

$\mathrm{V}_{\max }$ - volume of sample at maximum swelling.

The collected measurements were analyzed using descriptive statistics and analysis of variance (low significance differences test and Tukey test). Statistical calculations were performed in Statistica software and for visualization we used the R language.

\section{RESULTS AND DISCUSSION}

The trees on the plantation showed large variation in stem thickness. The average diameter at breast height equaled $25.78 \mathrm{~cm}$, with values for individual specimens ranging from 15.2 to $38.5 \mathrm{~cm}$ (Tab. 1). Wood properties show a deeper look into whole population, a total of 971 samples from 28 trees were tested. The coefficient of variability was relatively high for diameter (22\%) in compare with wood density which fluctuated at very low level between $9 \%$ and $11 \%$ (Tab. 1).

Tab. 1: Measured features for the whole population of clones grown on the plantation. Basic statistics.

\begin{tabular}{|l|c|c|c|c|c|}
\hline & $\begin{array}{c}\mathrm{d} 1.3 \\
(\mathrm{~cm})\end{array}$ & $\begin{array}{c}\mathrm{CS} 0 \% \\
(\mathrm{MPa})\end{array}$ & $\begin{array}{c}\mathrm{CS}>30 \% \\
(\mathrm{MPa})\end{array}$ & $\begin{array}{c}\mathrm{DD} \\
\left(\mathrm{kg} \cdot \mathrm{m}^{-3}\right)\end{array}$ & $\begin{array}{c}\mathrm{BD} \\
\left(\mathrm{kg} \cdot \mathrm{m}^{-3}\right)\end{array}$ \\
\hline Min & 15.2 & 32.83 & 11.26 & 376.90 & 345.32 \\
\hline Max & 38.5 & 94.49 & 24.85 & 746.44 & 598.01 \\
\hline Mean & 25.78 & 65.39 & 16.60 & 537.89 & 446.50 \\
\hline Sd & 5.65 & 10.02 & 2.54 & 60.52 & 41.75 \\
\hline $\mathrm{C}_{\mathrm{V}}$ & 22 & 15 & 15 & 11 & 9 \\
\hline $\mathrm{N}$ & 28 & 248 & 264 & 278 & 277 \\
\hline
\end{tabular}

The two types of wood density showed different distribution of population which is clearly visible in the violin plots (Fig. 2).

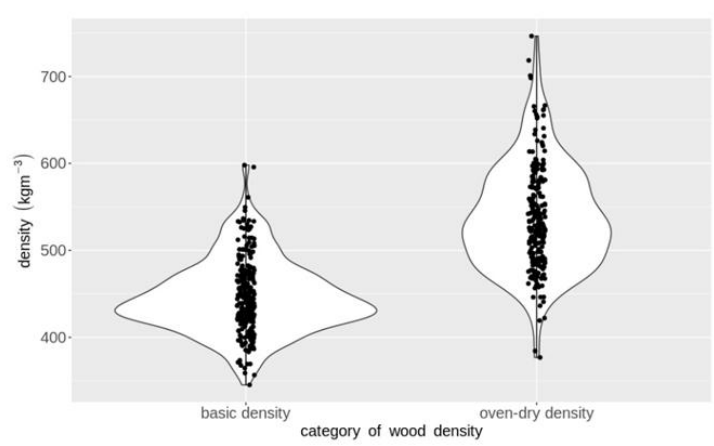

Fig. 2: Distribution of basic wood density and dry wood density in birch samples. 
In the case of basic density there were more samples around the median (the center of the violin appears much wider) than in the case of oven-dry density. The distance between maximum and minimum is also shorter for basic density $\left(252.78 \mathrm{~kg} \cdot \mathrm{m}^{-3}\right)$ than for dry density $\left(369.54 \mathrm{~kg} \cdot \mathrm{m}^{-3}\right)$ which points to more stable distribution in BD. Standard deviation also indicate greater fluctuation in the case of oven-dry density (Tab. 1).

The mean density of oven-dry wood is $537.89 \mathrm{~kg} \cdot \mathrm{m}^{-3}$ which is $91 \mathrm{~kg} \cdot \mathrm{m}^{-3}$ higher than basic density, indicating that the basic density is lower by $16 \%$. Difference were confirmed statistically using Mann-Whitney test at the level $\alpha=0,05$. Density in oven-dry samples varies much more than density in green samples. We can see that distance between first and third quartiles are longer for oven-dry samples (Fig. 3).

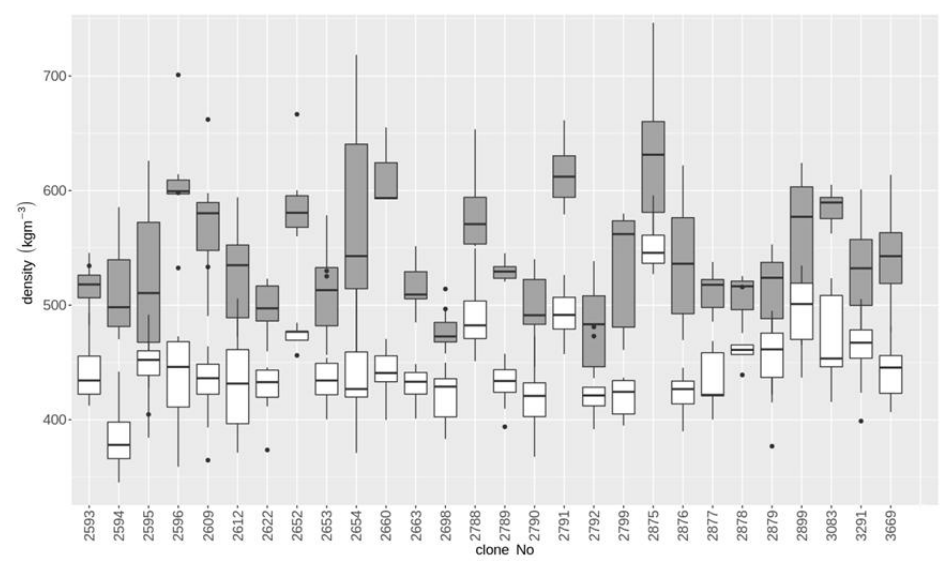

Fig. 3: Standard boxplot of oven-dry density (grey) and basic density (white) of 28 birch clones. Horizontal line - median, box-1st and 3rd quartile, vertical lines - whiskers, dots-outliers.

Radial distribution of the analyzed properties is rather typical for tree trunks, with all value increasing from pith to bark. We observed that value of samples connected with water $\left(\mathrm{CS}_{>30 \%}\right.$ and $\mathrm{BD}$ ) showed a relatively mild and stable increase (Figs. 4, 5). There is complete different situation in case of oven-dry samples (Figs. 6, 7) were the increase was not distinct in all cases. Confidence level also takes high values.

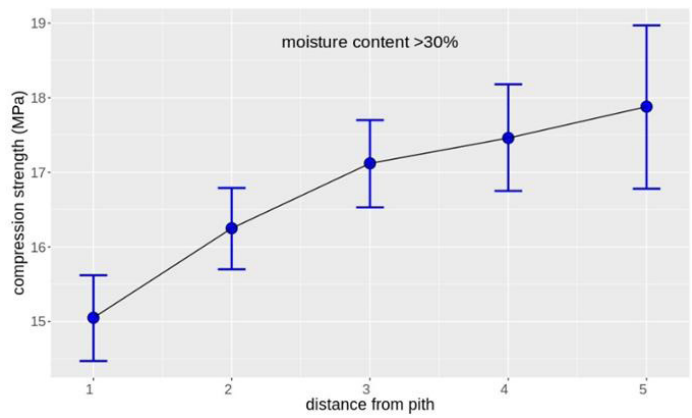

Fig. 4: Average compression strength with confidence level (+0.95) for birch samples over fiber saturation point. 
Generally in all cases we observe that green wood shows gentle variation but for oven-dry samples the behaviour is extreme. This currently leads to difficulties in planning the use of wood as a material.

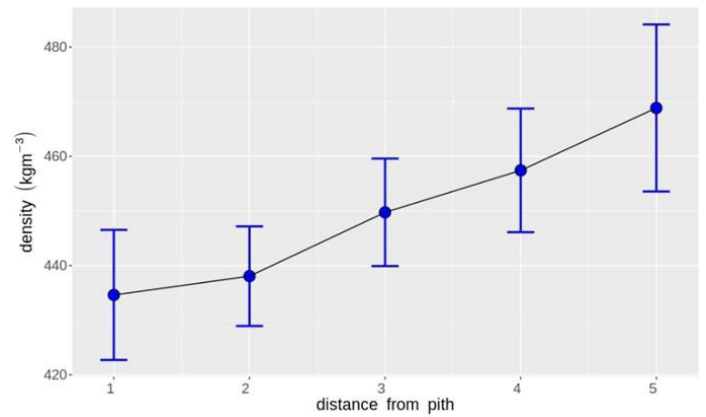

Fig. 5: Average basic density $\left(\mathrm{kg}_{\mathrm{g}} \mathrm{m}^{-3}\right)$ with confidence level (+0.95) in birch samples.

We observed a very large difference in the strength of tested samples with two levels of moisture content. The mean compression strength of oven-dry samples $\left(\mathrm{CS}_{0 \%}\right)$ was close to four times higher $(65.39 \mathrm{MPa})$ than that of the green $\left(\mathrm{CS}_{>30 \%}\right)$ samples $(16.6 \mathrm{MPa})$.

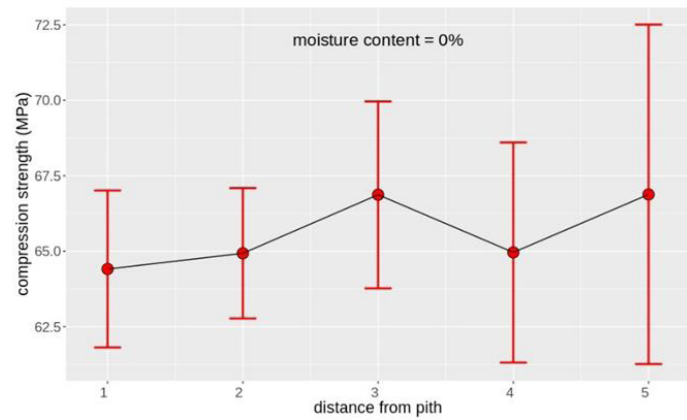

Fig. 6: Average compression strength with confidence level (+0.95) for tested birch samples at moisture content of $0 \%$.

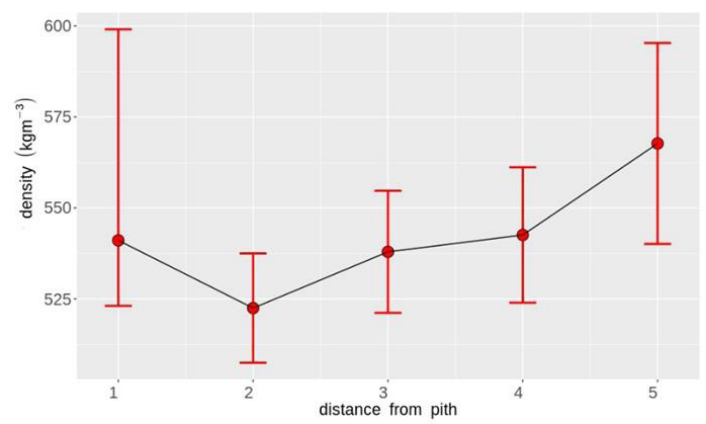

Fig. 7: Average oven-dry density $\left(\mathrm{kg}^{-3}\right)$ with confidence level (+0.95) in birch samples. 
An examination of the entire clone population showed that the compression strength of samples tested in dry conditions fluctuates much more than that of the green samples (Figs. 8, 9). The mean difference between the first and third quartile (Q1-Q3) in clones tested at $0 \%$ moisture content was $13 \mathrm{MPa}$. Green samples (moisture content of wood > 30\%) produced a relatively narrow range of compression strength values and the mean difference (Q1-Q3) was only $4 \mathrm{MPa}$. These differences are based on absolute values, if we compare relative values, fluctuations of compression strength in both cases $\left(\mathrm{CS}_{0 \%}\right.$ and $\left.\mathrm{CS}_{>30 \%}\right)$ are identical and equaled $15 \%$ (Tab. 1). Median in most of clones appears in to the center of the frame or near to center (Fig. 8), hence that population shows rather symmetrical value distribution. In a few clones we observed asymmetrical distribution.

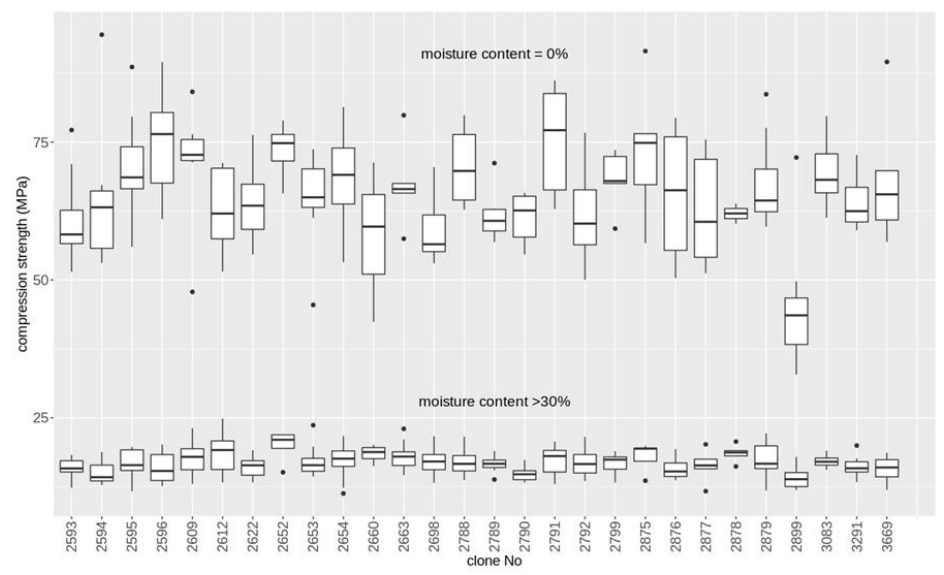

Fig. 8: Standard boxplot of compression strength of 28 birch clones with different moisture content. Horizontal line - median, box-1st and 3rd quartile, vertical lines - whiskers, dots-outliers.

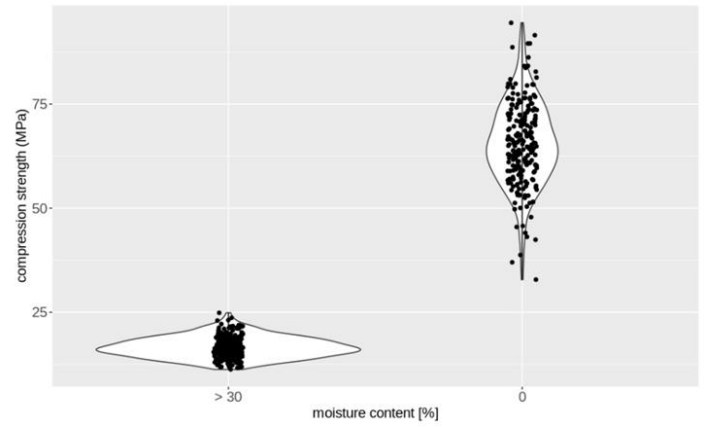

Fig. 9: Distribution of compression strength in different levels of moisture content.

The mean strength of most clones fluctuates within similar values. It is difficult to indicate especially strong specimens. Among the samples tested at higher moisture content a high mean was recorded for clones 2612 and 2652, while for oven-dry samples high means were obtained for clones 2596, 2652 and 2791. There was no real statistical difference between the tested clones and the entire population. However, it was relatively easy to identify the specimen with the lowest 
strength values, clone 2899, which gave the worst results in both tests. Low strength properties were also recorded for samples from clone 2790. In the case of these weak clones, the differences from the rest of the population were confirmed as statistically significant.

Differences between the wood properties tested in most clones were observable, although they were not statistically significant in most cases. We found significant differences (LSD test) for clones 2596, 2652, 2660, 2698, 2791, 2875 and 2899. A more restrictive test (the Tuckey test) confirmed significant differences only for clone 2899 . This may be result of the high variation in properties within a tree and the limited number of samples. No dependence was found between the properties tested and stem diameter in the analyzed trees. The plantation from which the wood was harvested was only 23 years old at the time of felling, greater differences appear to be observed in older trees.

\section{DISCUSSION}

The biometric features of trees are generally similar on most plantations oriented for wood production. In this case, we observed very large differences in diameter at breast height which ranged between 15 and $37 \mathrm{~cm}$ for various clones. Because the age (23 years) and conditions are the same, the difference probably results only from genetic variations between clones. The variations in diameters are related to the number of samples that was possible to obtain for testing purposes. We are aware that one sample tree for each clone represents low value, but at this time it is not possible to obtain more trees. This is a pilot study, and we expect that information obtained from single trees will be verified in subsequent research at the next stages of the plantation.

The average basic density obtained in this study $\left(446.5 \mathrm{~kg} \cdot \mathrm{m}^{-3}\right)$ is a much lower than that reported by Lachowicz et al. (2019) who obtained higher values for various Polish provenances $\left(\right.$ mean $\left.=528 \mathrm{~kg} \cdot \mathrm{m}^{-3}\right)$. However, because the populations investigated were much older, results may not be directly comparable. Only one of the populations tested by Lachowicz et al. (2019) gave a similar result $\left(447 \mathrm{~kg} \cdot \mathrm{m}^{-3}\right)$ and this was found in Łobez District and consisted of relatively young trees (30-years). Other authors have reported lower mean values for birch in Poland, Helińska-Raczkowska and Fabisiak (1995) gave $480 \mathrm{~kg} \cdot \mathrm{m}^{-3}$. Basic density in birch varies within a wide range: between 375 and $590 \mathrm{~kg} \cdot \mathrm{m}^{-3}$ (Helińska-Raczkowska 1996), or between 400 and $652 \mathrm{~kg} \cdot \mathrm{m}^{-3}$ (Lachowicz et al. 2019). Values depend on various factors, including age, habitat, geographic location and others (Lachowicz et al. 2019, Repola 2006).

In this study only a small change in wood density was observed between pith and bark. Basic density increased from 435 to $470 \mathrm{~kg} \cdot \mathrm{m}^{-3}$, dry density from 525 to $557 \mathrm{~kg} \cdot \mathrm{m}^{-3}$. Birch has a diffuse porous wood, and so the structure of the wood tissue is quite similar across the whole cross-sectional area. The increasing tendency is probably a mechanical response of the stem to the load of the crown mass. The crown undergoes extensive growth in the early phase of a young plantation. It should be emphasized that we studied a young plantation with trees growing in loose conditions. In older trees major changes have been observed (Heräjärvi 2004). A relatively large increase in basic density was reported by that author for mature trees of Betula pendula, with values increasing from 480 near the pith to $520 \mathrm{~kg} \cdot \mathrm{m}^{-3}$ (or even $550 \mathrm{~kg} \cdot \mathrm{m}^{-3}$ ) near the bark (Heräjärvi 2004). The same author reported a lower radial increase of basic density for Betula pubescens.

The strengthening of wood is accompanied by a reduction in its moisture content, as has been described in other works (Kollman and Côté 1967), and this features has also been as a helpful factor for wood quality estimation (Szymański et al. 2013). Generally the relationship between 
wood strength and moisture content has been subject of several studies (Gerhards 1982, Silva et al. 2012, Jakubowski et al. 2011). Changes in compression strength in our research were observed only in extreme conditions ( $0 \%$ moisture content), but this conditions reflect the behavior of samples after drying. We observed that the variation in strenght in most of the population is similar and not statistically differ, although some samples gave extreme values, which are probably symptoms of disturbances in the wood structure. For this reason, observations of strength under extreme moisture content conditions may be more helpful than the standard level of $12 \%$ used for crash tests.

Wood properties considered in relation to distance from pith show the generally typical increasing trend also reported by other authors (Heräjärvi 2004). Variation in compression strength was greater for oven-dry samples (Fig. 4, 6), and appears to be less predictable because of the more extreme values. Problems of testing birch samples during a drying process were studied by Zongying et al. (2016). Authors pointed that radial drying stress in birch disks may be the result of combination of several factors connected to shrinkage anisotropy.

\section{CONCLUSIONS}

1. Trees from a seed plantation having the same age and environmental conditions show large variation in the diameter at breast height, but relatively low variability in wood density. Coefficient of variability was $22 \%$ for diameter of breast height, $11 \%$ for oven-dry density and $9 \%$ for basic density.

2. The tests revealed large differences in compression strength for different moisture contents. The compression strength at $0 \%$ moisture content was four times higher $(65 \mathrm{MPa})$ than the strength at humidity above the fiber saturation point $(16.6 \mathrm{MPa})$. The results of tests carried out at $0 \%$ moisture content were also characterized by highly extreme values.

3. Most of clones had similar properties within the limits of statistical errors, but a few clones produced statistically significantly lower values. It appears to be too early for final clone selection at this stage of research, but the current results may be helpful for later tests.

4. In view of the rapid growth of plantations and the fact of preservation of the genotype through vegetative propagation, such experimental results should be verified for the purpose of developing a potential method to produce high-quality timber in short periods.

\section{REFERENCES}

1. Baliuckienè, A., Baliuckas, V., 2006: Genetic variability of Silver birch (Betula pendula L.) wood hardness in progeny testing at juvenile age. Baltic Forestry 12(2): 134-140.

2. Bijak, S., Zasada, M., Bronisz, A., Bronisz, K., Czajkowski, M., Ludwisiak, Ł., Wojtan, R., 2013: Estimating coarse roots biomass in young silver birch stands on post-agricultural lands in central Poland. Silva Fennica 47(2): 1-14.

3. Bronisz, K., Strub, M., Cieszewski, C., Bijak, S., Bronisz, A., Tomusiak, R., Zasada, M., 2016: Empirical equations for estimating aboveground biomass of Betula pendula growing on former farmland in central Poland. Silva Fennica 50(4): 1-17, id 1559.

4. Cameron, A.D., 1996: Managing birch woodlands for the production of quality timber. Forestry 69(4): 357-371.

5. Gartner, B. L., 2005: Assessing wood characteristics and wood quality in intensively managed plantations. Journal of Forestry 103: 75-77. 
6. Gerhards, C. C., 1982: Effect of moisture content and temperature on the mechanical properties of wood: an analysis of immediate effects. Wood and Fiber V 14(1): 4-36.

7. Haapala, A., Kontunen-Soppela, S., Oksanen, E., Rousi, M., MolaYudego, B., 2017: Tree provenance affects the growth and bioenergy potential of juvenile Silver birch. In 6th. International Scientific Conference on Hardwood Processing: Proceedings. Natural Resources Institute Finland, pp. 310-318.

8. Helińska-Raczkowska, L., Fabisiak E., 1995: Zależność między długością elementów anatomicznych i gęstością drewna brzozy (Betula pendula Roth). (Relation between the length of anatomical elements and the density of birch wood (Betula pendula Roth)). Prace Komisji Technologii Drewna PTPN 14, Pp 43-48.

9. Helińska-Raczkowska, L., 1996: Zmienność wilgotności i gęstości drewna w świeżo ściętych pniach brzozy (Betula pendula Roth). (Wood moisture content and density variation in the freshly cut birch (Betula pendula Roth) stem). Folia Forestalia Polonica. Seria B. Zeszyt 27: 23-30.

10. Heräjärvi, H., 2004: Variation of basic density and Brinell hardness within mature Finnish Betula pendula and B. pubescens stems. Wood and Fiber Science 36(2): 216-227.

11. Hynynen, J., Niemistö, P., Viherä-Aarnio, A., Brunner, A., Hein, S., Velling, P., 2010: Silviculture of birch (Betula pendula Roth and Betula pubescens Ehrh.) in northern Europe. Forestry 83: 103-119.

12. Jakubowski, M., Gonet, A., Kałuziński, D., 2013: Gęstość umowna drewna świerka pospolitego (Picea abies L. Karst) pozyskanego z plantacji nasiennej (Wood density of Norway spruce (Pice aabies L. Karst) harvested from seed orchard). Forestry Letters 106: 9-13.

13. Jakubowski, M., Tomczak, A., Jelonek, T. 2001: Compression strength along the grain in twin samples (wet and absolutely dry) coming from wood of wind- broken trees of Scots pine (Pinus sylvestris L.). Annals of Warsaw University of Life Sciences - SGGW. Forest and Wood Technology 74: 104-109.

14. Kelty, M. J., 2006: The role of species mixtures in plantation forestry. Forest Ecology Management 233(2-3): 195-204.

15. Klašnja, B.; Orlović, S., Galić, Z., Drekić, M., Vasić, V., Pilipović, A., 2008: Poplar biomass of high density short rotation plantations as raw material for energy production. Wood Research 53(2): 27-38.

16. Kollmann, F.F.P., Côté, W.A., 1968: Principles of wood science and technology I Solid wood. Springer-Verlag, Berlin, Heidelberg, New York. 592 pp.

17. Lachowicz, H., Paschalis-Jakubowicz, P., Wojtan, R., 2018: Multivariate analysis of the variability in the density of oven-dry wood of silver birch (Betula pendula Roth) in Poland. Drewno 61(201): 39-56.

18. Lee, S. J., Connolly, T., Wilson, S. McG., Malcolm, D. C., Fonweban, J., Worrell, R., Hubert, J., Sykes R. J., 2015: Early height growth of silver birch (Betul apendula Roth) provenances and implications for choice of planting stock in Britain. Forestry: An International Journal of Forest Research 88 (4): 484-499.

19. Maja, M. M., Kasurinen, A., Holopainen, T., Kontunen-Soppela, S., Oksanen, E., Holopainen, J. K., 2015: Volatile organic compounds emitted from Silver birch of different provenances across a latitudinal gradient in Finland. Tree Physiology 35(9): 975-986.

20. Margono, B. A., Potapov, P. V., Turubanova, S., Stolle, F., Hansen, M. C., 2014: Primary forest cover loss in Indonesia over 2000-2012. Nature Climate Change (4): 730-735. 
21. Mola-Yudego, B., Arevalo, J., Díaz-Yáñez, O., Dimitriou, I., Haapala, A., Filho, A. Selkimäki, M., Valbuena, R., 2017: Wood biomass potentials for energy in northern Europe: Forest or plantations? Biomass and Bioenergy 106: 95-103.

22. Przybylski, P., 2015: Are we narrowing genetic variability in seed orchards? An attempt to answer, based on the analysis of microsatellite DNA of grafts growing in Scots pine (Pinus sylvestris L.) seed orchard in the Forest District Susz. Leśne Prace Badawcze / Forest Research Papers 76(3): 240-249.

23. Repola, J., 2006: Models for vertical wood density of Scots pine, Norway spruce and birch stems, and their application to determine average wood density. Silva Fenika 40(4): 673-685.

25. Riege, D. A., Sigurgeirsson, A., 2018: Provenance variability in establishment of native downy birch in a 14-year trial in southwest Iceland. Icelandic Agricultural Sciences 31: 3-9.

26. Šefc, B., Trajković, J., Slavko, G., Radovan, D., Hasan, M., 2009: Selected tree characteristics and wood properties of two poplar clones. Wood Research 54(1): 15- 22.

27. Stibig, C.F., Achard, H.J., Carboni, F., S., Raši, R., Miettinen, J., 2014: Change in tropical forest cover of Southeast Asia from 1990 to 2010. Biogeosciences 11: 247-258.

28. Szaban, J., Kowalkowski, W., Karaszewski, Z., Jakubowski, M., 2014: Effect of tree provenance on basic wood density of Norway spruce (Picea abies [L.] Karst.) grown on an experimental plot at Siemianice Forest Experimental Station. Drewno 57(191): 135-143.

29. Szczukowski, S., Stolarski, M., 2013: Plantacje drzewi krzewów szybko rosnących jako alternatywa biomasy z lasu - stan obecny, szansei zagrożenia rozwoju (Plantations of fast growing trees and bushes as an alternative to biomass from the forest - current status, opportunities and threats to development). In: Gołos P., Kaliszewski A., 2013: Biomasa leśna na cele energetyczne. Instytut Badawczy Leśnictwa (ResearchForest Institute), Sękocin Stary. Pp 32-46.

30. Szymański, M., Pazdrowski, W., Szykowny, T., Nawrot, M., 2013: Wzmocnienie desorpcyjne jako podstawa oceny jakości drewna dębu szypułkowego (Quercus robur L.) i dębu burgundzkiego (Quercus cerris L.). (Desorption strengthening as a basis for the assessment of wood quality of pedunculate oak (Quercus robur L.) and Turkey oak (Quercus cerris L.)) Sylwan 157(11): 811-816.

31. Wang, X. W., Weng, Y. H., Liu, G. F., Krasowski, M., J., Yang, C. P. 2015: Variations in carbon concentration, sequestration and partitioning among Betula platyphylla provenances. Forest Ecology and Management 358: 344-352.

32. Wang, X., Zhao, D., Liu, G., Yang, C., Teskey, R., O., 2018: Additive tree biomass equations for Betula platyphylla Suk. plantations in Northeast China. Annals of Forest Science 75(2): 60.

33. West, P.W., 2006: Growing plantation forests. Springer-Verlag Berlin Heidelberg, 233 pp.

34. Zasada, M., Bijak, S., Bronisz, K., Bronisz, A., Gawęda, T. 2014: Biomass dynamics in young silver birch stands on post-agricultural lands in central Poland. Drewno 57(192): 29-39.

35. Zongying, F., Zhao, J., Lv, Y., Huan, S., Cai, Y.. 2016: Stress characteristics and stress reversal mechanism of white birch (Betula platyphylla) disks under different drying conditions. Maderas. Ciencia y tecnología 18(2): 361-372.

36. Zwoliński J., 2008: Rola leśnictwa plantacyjnego w warunkach kryzysu środowiskowego i surowcowego świata. (The role of plantation forestry in the conditions of environmental and raw material crisis in the world) Leśne Prace Badawcze/Forest Research Papers 69(4): 371-379. 
Marcin Jakubowski*, Arkadiusz Tomczak, Tomasz Jelonek

Witold Grzywiński

Poznan University of Life Sciences

FACUlty of Forestry

Department of Forest Utilisation

Wojska Polskiego 7iA

6o-625 Poznań

Poland

*Corresponding author: marcin.jakubowski@up.poznan.pl 